Anna Plaksej

Uniwersytet Wroctawski

\title{
ROLA BIOSTYMULACJI MÓZGU W UCZENIU SIĘ JĘZYKA ANGIELSKIEGO PRZEZ NASTOLATKÓW Z NIEPELNOSPRAWNOŚCIĄ INTELEKTUALNĄ W STOPNIU LEKKIM
}

\section{The role of brain bio-stimulation in learning English by mildly retarded teenagers}

The 21st century is the time of dynamic development of advanced technologies as well as creating and improving equal opportunities for those who have not had them so far. The appropriate and well adjusted education of people who are mentally retarded may turn out to be one of the most important ways to prepare them to live independently in their societies. In every Polish school at least one foreign language is taught and mostly it is English. Even though the idea of teaching English to mildly retarded students has always been controversial, the Ministry of Education in Poland decided to put it into practice. Consequently, since 2009 the junior high school graduation exam has included a component devoted to testing a foreign language. These changes made it necessary to increase the effectiveness of foreign language pedagogy.

A lower intelligence quotient, psycho-motor hyperactivity or emotional disturbance are factors that make the English language learning process more difficult for the mildly retarded students; however, they do not prevent it. The process may be facilitated by adjusting the teaching techniques and, thanks to new technologies, by diminishing hyperactivity and problems with concentration. The research conducted by the author showed that in case of mildly retarded students brain stimulation with the use of EEG Biofeedback influenced positively their learning English. The article describes in more detail the problems mentioned above and aims to present evidence supporting the assumption that brain bio-stimulation may have a positive impact on vocabulary retention in learning English by mildly retarded teenagers. 


\section{Czas nowych wyzwań}

XXI wiek to czas dynamicznego rozwoju zaawansowanych technologii oraz tworzenia i udoskonalania równych szans dla tych, którzy ich do tej pory nie mieli. Prawidłowa, czyli odpowiednio dostosowana edukacja osób z niepełnosprawnością intelektualną może być najważniejszym ze sposobów przygotowania ich do samodzielnego funkcjonowania w społeczeństwie. W każdej polskiej szkole uczniowie poznaja przynajmniej jeden język obcy i w przeważającej części jest to angielski. Pomimo, że idea nauczania języka obcego uczniów $\mathrm{z}$ niepełnosprawnością intelektualną $\mathrm{w}$ stopniu lekkim była kontrowersyjna, Ministerstwo Edukacji Narodowej zdecydowało się na wprowadzenie jej w życie. W wielu klasach zajęcia z języka obcego stanowiły wówczas często ciekawe urozmaicenie programu, a niektórzy nauczyciele potrafili nawet wykorzystać tę zmianę do celów terapeutycznych. Jednak od 2009 roku egzamin gimnazjalny dla uczniów z niepełnosprawnością intelektualną w stopniu lekkim obejmuje także język obcy (Wieruszewska 2007). Taka poważna zmiana to ogromne wyzwanie zarówno dla samych uczniów, jak i ich nauczycieli, którzy oprócz przybliżenia uczniom języka obcego musieli dodać kolejny cel w swojej pracy - przygotowanie do zdania egzaminu. W takich okolicznościach zmieniło się nieco podejście do przedmiotu, a podnoszenie skuteczności nauczania stało się absolutną koniecznością.

Jak wynika z doświadczeń nauczycieli języka angielskiego (Mąkosa 2001), można odnieść sukces $\mathrm{w}$ nauczaniu języka obcego uczniów z niepełnosprawnością intelektualną. Jednak, oprócz zastosowania metod i technik nauczania, które są odpowiednio zmodyfikowane i dostosowane do indywidualnych potrzeb ucznia $i$ grupy oraz dopasowania standardowego programu nauczania do możliwości intelektualnych osób ze specjalnymi potrzebami edukacyjnymi, nauczyciele muszą stale poszukiwać nowych sposobów na radzenie sobie z problemem krótkiego czasu skupienia swoich uczniów i starać się go w jak największym stopniu eliminować. Proces nauczania i uczenia się może zachodzić tylko przy odpowiedniej koncentracji, uwaga ucznia jest bowiem jednym z najważniejszych czynników warunkujących ten proces i należy ja traktować szczególnie i priorytetowo.

Nowe technologie XX wieku ułatwiaja życie ludzi na niezliczoną ilość sposobów i choć w większości szkół znajduja się komputery i nowoczesne oprogramowanie, jest jeszcze wiele innych ciekawych ulepszeń, jakie można byłoby wprowadzić w dziedzinie edukacji dzięki nowym rozwiązaniom technicznym. W 1999 roku urządzenie o nazwie EEG Biofeedback po raz pierwszy pojawiło się w Polsce (EEG Instytut Biofeedback 2010). Choć wcześniej popularne w Stanach Zjednoczonych, u nas początkowo było nieznane, podczas gdy dziś jest stosowanym urządzeniem terapeutycznym, a specjalistyczne kursy na licencję terapeutyczna prowadzone są na czterech poziomach przez profesjonalne ośrodki szkoleniowe. Ogólnie zdefiniowanym celem terapii jest objęcie lepszej 
kontroli nad własnym mózgiem, a dokładnie nad umiejętnościa skierowania swojej uwagi i koncentracji na określony aspekt. Duża część pacjentów poddawanych takiej terapii to osoby cierpiące na ADHD, u których zaobserwowano znaczną poprawę nawet $\mathrm{w}$ porównaniu $\mathrm{z}$ efektami leczenia farmakologicznego. Na podstawie takich właśnie informacji powstało moje założenie, że terapia przy użyciu EEG Biofeedback może być pomocna w efektywnym nauczaniu języka angielskiego w przypadku osób z niepełnosprawnością intelektualną w stopniu lekkim. Postanowiłam zaprojektować i przeprowadzić badanie pre-eksperymentalne w grupie uczniów z gimnazjum z jednego ze specjalnych ośrodków szkolno-wychowawczych, zwłaszcza, że według mojej wiedzy takie badanie nie zostało wcześniej wykonane. Ośrodek jest w posiadaniu urządzenia EEG Biofeedback i dysponuje własnymi licencjonowanymi terapeutami. Zanim jednak przejdę do przedstawienia procesu badania i omówienia wyników, pragnę poświęcić kilka słów tematowi niepełnosprawności intelektualnej, a następnie neurofizjologii, w celu lepszego zaprezentowania istotnych okoliczności towarzyszących badaniu.

\section{Niepełnosprawność intelektualna}

Przypadki osób mniej sprawnych intelektualnie od innych były zawsze zauważane na tle społeczeństwa, ale długo nie było wiadomo, co jest przyczyną owej odmienności, a już na pewno nie podejrzewano, że przyczyna może znajdować się w głowie. $Z$ powodu braku fachowej wiedzy, dawniej uznawano, że to, co dziś jest określane mianem niepełnosprawności intelektualnej, było nieumiejętnością dostosowania się jednostki do standardów współżycia społecznego oraz poprawnego funkcjonowania $z$ innymi osobami w normalnym środowisku. Dla wielu osób o obniżonej sprawności umysłowej samodzielne codzienne życie było bowiem wielkim wyzwaniem, a w niektórych przypadkach było ono wręcz niemożliwe. Choć przez długi czas takie osoby chowano w domach i wstydzono się ich, później uznano, że korzystniej dla społeczeństwa będzie edukować niepełnosprawnych intelektualnie niż zapewniać im dożywotnio opiekę i warunki materialne. Kiedy w 1905 roku Binet i Simon (Patton, Polloway i Smith 2000: 81) wprowadzili test sprawdzający umiejętności umysłowe, problem po raz pierwszy zaczął być postrzegany w kategoriach trudnych aspektów kompetencji kognitywnej. W latach 30-tych ubiegłego stulecia oszacowano, że uczniowie z niepełnosprawnością intelektualną stanowili zdecydowaną większość wszystkich uczniów niepełnosprawnych (ibid.). Jak jednak definiuje się pojęcie niepełnosprawności intelektualnej? Według definicji obecnych w fachowej literaturze jest to słabsze funkcjonowanie mentalne odzwierciedlane np. przez obniżony iloraz inteligencji w stosunku do przyjętej normy, wynoszącej średnio (IQ) 100, któremu towarzyszą także problemy adaptacyjne (Barnow, Ermer, Dittmann i Stieglitz 2005: 208). Test na inteligencję służy jednak tylko i wyłącznie przekazaniu informacji o tym, jak 
duża jest dysfunkcja, która może być spowodowana takimi czynnikami jak m.in. obciążenie genetyczne (np. dziedziczność), niewłaściwe środowisko rozwoju, patologiczne nieprawidłowości ośrodkowego układu nerwowego, urazy mózgu oraz nieprawidłowy rozwój biologiczny, również w okresie życia płodowego (Siwek 2006: 39-40). W klasyfikacji niepełnosprawności intelektualnej podaje się cztery stopnie, choć dawniej rozróżniano tylko trzy. Przez wiele lat ubiegłego stulecia organizacje takie jak Amerykańskie Towarzystwo Badań nad Upośledzeniem Umysłowym (AAMR), Amerykańskie Towarzystwo Psychiatryczne (APA) a także Światowa Organizacja Zdrowia (WHO) opracowywały i udoskonalały swoje klasyfikacje stopni niepełnosprawności intelektualnej w oparciu o obserwacje oraz testy kliniczne. To sprawiło, że w zależności od autora klasyfikacji, przedziały dla poszczególnych stopni czasami różnią się kilkoma punktami. Według Międzynarodowej Klasyfikacji Chorób (ICI-10 opracowanej przez WHO) należy przyjąć, że mówimy o stopniu głębokim, gdy IQ wynosi poniżej 20 (Siwek 2006: 61, podobnie Włodarski 1976: 52). To najcięższe przypadki i osoby takie nie są w stanie uczyć się w ogóle. Ponadto nie nabywają cech rozwojowych takich jak chodzenie, mówienie czy samodzielne jedzenie. Nie rozpoznają twarzy, ale potrafią reagować na kilka słów, najczęściej gdy są to bodźce sygnalizujące pokarm. Nigdy nie stają się samodzielni. IQ na poziomie 20-34 to niepełnosprawność znaczna (Siwek 2006: 61, podobnie Seifert 1983: 276). Cechuje się podstawową sprawnością fizyczną i umiejętnością wykonania prostych zadań pod nadzorem, ale elementarne funkcje językowe bądź kognitywne pojawiają się rzadko. Pamięć bardzo nietrwała, brak dowolnego skupienia uwagi, a rozwój intelektualny w dorosłości jest porównywalny $\mathrm{z}$ dzieckiem w wieku 5-6 lat. Kolejny stopień niepełnosprawności to umiarkowany IQ od 35 do 49 (ibid.). To przypadki wyuczalne, tzn. osoby takie czasem opanowują czytanie, ale bez zrozumienia oraz pisanie (pojedyncze wyrazy). Z odpowiednią pomoca są w stanie wykonać bardzo proste czynności. Reagują na otoczenie i choć funkcja mowy jest mocno zaburzona, bywa, że potrafią komunikować się werbalnie w prosty sposób. Widoczna jest pogorszona koordynacja ruchowa. Jeśli osoby niepełnosprawne intelektualnie w stopniu umiarkowanym otrzymaja wczesne wsparcie i rehabilitację, mogą w nielicznych zadaniach osiagnąć samodzielność. Ostatni stopień niepełnosprawności intelektualnej to lekki, o ilorazie inteligencji od 50 do 69 (Siwek 2006: 61), lecz należy zauważyć, że ustalenie wyraźnej granicy pomiędzy umiarkowanym a lekkim stopniem omawianej niepełnosprawności czasami może sprawiać trudności ze względu na indywidualne cechy u konkretnych osób. Niemniej jednak osoby należące do tej grupy są w stanie uczyć się w szkole pod warunkiem, że będzie ona do nich dostosowana programowo. W wieku od 15 do 21 lat osiagają rozwój intelektualny 8-12-latka. Mowa rozwija się z opóźnieniem i bywa zaburzona - od problemów z artykulacją po trudności z werbalnym wyrażaniem swoich myśli. Nie rozumieja wielu słów i skomplikowanych pojęć, ale za to mogą nauczyć się zawodu i w 
czynnościach manualnych nie widać obniżonej sprawności intelektualnej. Osobom niepełnosprawnym umysłowo w stopniu lekkim można w dużym stopniu pomóc przystosować się do samodzielnego funkcjonowania w społeczeństwie poprzez odpowiednią edukację, nauczenie zawodu, a nawet, jak się w ostatnich latach okazało - nauczanie języka obcego. Ponieważ ta grupa jest w centrum zainteresowania niniejszego artykułu, poświęcę jej nieco więcej uwagi. Obecnie uważa się, że niepełnosprawność intelektualna to przypadłość 2 do 3\% całej populacji (Zegarek i Roczniak 2001). W przypadku nauczania osób o specjalnych potrzebach edukacyjnych należy zwrócić uwagę na ograniczenia i możliwości takich uczniów. Do kategorii tych pierwszych niewątpliwie należy słabo rozwinięte myślenie logiczne, odwracalne oraz abstrakcyjne, które w normalnym rozwoju umysłowym pojawia się około 10-11 roku życia. W konsekwencji trudno takim uczniom wyobrazić sobie pojęcia abstrakcyjne i je zrozumieć, w przeciwieństwie do konkretnych przedmiotów. Uogólnianie, kategoryzowanie i porównywanie rzeczy lub pojęć jest tu zadaniem trudnym. Pojawiają się kłopoty z normalnie pracującą pamięcią, tzn. albo jest ona słaba albo wręcz fotograficzna. Najczęściej jest to jednak pozbawiona zrozumienia treści pamięć mechaniczna, co tłumaczy łatwość uczniów w zapamiętywaniu wierszy czy piosenek. Oprócz ograniczeń kognitywnych, należy przedstawić również problemy emocjonalne i psychomotoryczne. Często u osób z niepełnosprawnością intelektualną w stopniu lekkim zdarza się brak równowagi zarówno w odczuwaniu, jak i okazywaniu uczuć, np. niekontrolowana agresja lub znikoma zdolność do nawiązywania interakcji z innymi. Wielu uczniom brakuje motywacji do nauki, a inni wykazują negatywne podejście do życia w ogóle. Zazwyczaj niedojrzałość społeczna i problemy natury emocjonalnej sa skutkiem trudnych, a niekiedy wręcz patologicznych warunków środowiskowych uczniów. Poza ograniczeniami, należy jednak także pamiętać o tym, że mimo trudności, uczniowie z niepełnosprawnością intelektualną w stopniu lekkim są w stanie opanować program szkolny do poziomu piątej klasy podstawowej szkoły masowej i potrafią nauczyć się zawodu. Gdy zadba się o odpowiednią formę przekazu - można odnieść sukces w edukacji specjalnej. Przy doborze skutecznych technik, natomiast, należy pamiętać o tym, że wiele osób z niepełnosprawnością intelektualną ma dominującą prawą półkulę mózgową i warto przeanalizować cechy, możliwości i naturalne predyspozycje z związane z tym faktem, np. przekazywać treść obrazem, dźwiękiem, za pośrednictwem dotyku, węchu czy nawet smaku. To prosty sposób na np. zwrócenie i zatrzymanie uwagi uczniów, co jest niezwykle ważne w nauczaniu i trudne. Nie o technikach nauczania jednak będzie tu mowa. Przedmiotem tych rozważań jest właśnie koncentracja i skupienie ucznia. Aspekt ten jest bardzo istotny, gdyż może stać za sukcesem bądź porażką w trwałym zdobywaniu wiedzy przez uczniów z niepełnosprawnością intelektualną. Żadna ilość powtórzeń danego słowa czy zagadnienia nie pomoże, jeśli osoba, do której się kierujemy, nie skupi się na tym, o czym się do niej mówi. Z tym właśnie uczniowie mają największy 
problem $-z$ koncentracja. I nie jest to spowodowane wyłącznie ich brakiem samodyscypliny. To typowa cecha uczniów z niepełnosprawnością intelektualną - nadaktywność psychoruchowa. Wielu z nich wykazuje objawy typowe dla zespołu ADHD. Bardzo trudno jest przy pomocy tradycyjnych praktyk na lekcji zaradzić temu problemowi, gdyż swoje źródło ma on w mózgu, a dokładnie w zaburzonej proporcji różnych fal mózgowych. Istnieje jednak urządzenie EEG Biofeedback, w które wiele specjalnych ośrodków szkolno-wychowawczych w Polsce jest wyposażonych, i może ono pomóc zredukować bądź nawet zlikwidować problem nadpobudliwości. Dlatego pokrótce przyjrzyjmy się bliżej temu, jak działa ludzki mózg i w jaki sposób to urządzenie treningowe jest w stanie pomóc uczniom z niepełnosprawnością intelektualna.

\section{Z pomocą neurotechnologii}

Neurotechnologia zajmuje się obserwacją struktury i fizjologii mózgu wraz z procesami, które $\mathrm{w}$ nim zachodza. To nauka, która łączy $\mathrm{w}$ sobie wiedzę $\mathrm{z}$ dziedziny medycyny, psychologii i najnowszych odkryć w biomedycynie, a jej celem jest rozwinięcie i zoptymalizowanie motorycznych, intelektualnych i emocjonalnych funkcji mózgu (Pakszys 2006). Mózg pracuje dzięki impulsom elektrycznym, które są przekazywane między komórkami nerwowymi, a ich częstotliwość i ilość bezpośrednio przekłada się na wydolność intelektualną. W zależności od tego, w jakim stanie się znajdujemy, częstotliwości fal mózgowych bywają różne. Czasem jest odwrotnie - to zmienna aktywność fal mózgowych, spowodowana czynnikami zewnętrznymi i wewnętrznymi, sprawia, że doświadczamy różnych stanów świadomości. Jedno natomiast jest pewne: mózg łatwo dostosowuje częstotliwość swoich fal do środowiska, które na niego oddziałuje i ludzie już dawno odkryli, że np. dynamiczne dźwięki muzyki czy błyski światła mogą działać pobudzająco, podczas gdy jednostajny dźwięk jadącego pociagu po szynach czy szum morza jest w stanie ukołysać nas do snu. Wszystko to dzieje się dlatego, że fale mózgowe dostrajają się do czynników z otoczenia. Mając tę wiedzę, naukowcy z NASA opracowali urządzenie, które dziś jest przedstawiane jako EEG Biofeedback - połączenie encefalografii, obecnie jednej z wiodących technik czynnościowej diagnostyki mózgu, i komputera, a dokładnie - gry komputerowej. Dziś jednak, zamiast astronautom, możemy pomóc osobom z niepełnosprawnością intelektualną w stopniu lekkim, np. w procesie uczenia się języka obcego.

Przedstawię teraz rodzaje fal mózgowych, które każdej doby kierują naszym umysłem. Zasadniczo jest ich cztery rodzaje. Pierwszy z nich to fale delta, z częstotliwością od 0,4 do $4 \mathrm{~Hz}$, występujące podczas głębokiego snu i szacuje się, że przez większość czasu spania mózg pozostaje właśnie w stanie delta. Jedynie chwilowe wyładowania fal theta i alfa są oznaką snów. W stanie delta ciało regeneruje się i odzyskuje siły (EEG Instytut 2006, Pakszys 2006). Drugi rodzaj fal mózgowych to fale theta o częstotliwości 4 to $8 \mathrm{~Hz}$ oferujące 
stan głębokiej relaksacji $i$ transu, czyli spanie $z$ obecnością snów $i$ podświadomości. To idealny stan dla medytacji i hipnozy, gdyż dzięki falom theta nie odczuwamy stresu, napięcia ani żadnych innych negatywnych uczuć, a poziom endorfin rośnie. W stanie między jawą a snem, lecz przy małym udziale fal alfa i beta, możemy lekko odczuwać zewnętrzne czynniki za pomoca zmysłów. Fale alfa są neutralne, od 8 do $12 \mathrm{~Hz}$ i osoba w tym stanie świadomości jest zrelaksowana, wzmacnia się bierna uwaga, pamięć oraz pozytywne myślenie. Pojawia się podatność na sugestie. Ostatni typ fal mózgowych, od 13 do nawet $35 \mathrm{~Hz}$ to fale beta, obejmujące m.in. fazę rytmów sensomotorycznych (SMR). To stan wysokiej koncentracji (np. podczas pracy umysłowej) występujący w obecności niskich wartości beta, których obecność pomogłaby w likwidowaniu nadpobudliwości psychomotorycznej u dzieci. Im jednak wyższe wartości beta, tym większe napięcie i stres. Rozróżnia się także fale gamma, które występują w stanach ekstremalnych doświadczeń psychologicznych (EEG Instytut 2006, Pakszys 2006).

W przypadku osób z zaburzoną koncentracja, występuje zbyt wiele fal alfa, a zbyt mało niskich fal beta. Rolą urządzenia EEG Biofeedback jest zmiana tych proporcji poprzez trening polegający na tym, że osoba ma założony na głowę czujnik fal mózgowych i gra w grę komputerowa, którą steruje wyłącznie własnymi myślami. Sukces w grze jest uzależniony od poziomu skupienia, a biologiczne sprzężenie zwrotne (sygnały własnego ciała) zapewnia pozytywne wzmocnienie w przypadku dobrego pokierowania rozwojem wydarzeń w grze. Innymi słowy, jeśli osoba w trakcie sesji terapeutycznej wystarczająco mocno skoncentruje swoją uwagę na osiągnięciu właściwego celu w grze (np. samochód jadacy w granicach drogi, a nie poboczem), cel ten zostanie osiagnięty i prawidłowy tok wydarzeń gry, będący nagrodą - pozytywnym wzmocnieniem, jest widoczny dla tej osoby na ekranie monitora i zachęca do powtórzenia czynności. Jednocześnie, brak odpowiedniego skupienia uwagi może skutkować tym, że samochód będzie jechał poboczem. Dla osób z zaburzoną koncentracja takie skupienie uwagi bywa czasem dużym wysiłkiem, ale jest jednocześnie ćwiczeniem regulującym częstotliwość fal mózgowych, ponieważ jak każde ćwiczenie fizyczne, prowadzi do lepszej sprawności dzięki wielokrotnym powtórzeniom. To oznacza, że mózg, dzięki swojej elastyczności, uczy się w ten sposób wchodzić na odpowiednie częstotliwości fal mózgowych w konkretnych sytuacjach - w tym przypadku - w stanie wytężonej, celowej koncentracji uwagi. Taki trening pomaga osobie stymulowanej nauczyć się kontroli nad własną umiejętnościa koncentracji, a wielokrotne treningi pomagają poprawnie nastroić fale mózgowe i ich zaburzone wartości skorygować do częstotliwości normalnych dla danej sytuacji. Pozwala to w znacznym stopniu zredukować lub zlikwidować zaburzenie nadpobudliwości (EEG Instytut 2006), a co za tym idzie problemy z koncentracją (Pakszys 2006; Lamparska-Warchalska 2010). Założenie, iż skupienie uwagi jest czynnikiem warunkującym sukces w uczeniu się pozwoliło mi upatrywać nadziei, że sesje stymulujące z wykorzystaniem 
EEG Biofeedback pomogą uczniom z niepełnosprawnościa intelektualną w stopniu lekkim lepiej koncentrować się na lekcjach języka angielskiego i więcej z nich wynosić. Dlatego przeprowadziłam badanie pre-eksperymentalne i sprawdziłam, czy taka stymulacja mózgu może mieć jakikolwiek pozytywny wpływ na zapamiętywanie angielskiego słownictwa na lekcjach języka obcego. 


\section{Badanie}

\section{Grupa}

Uczestnikami badania byli uczniowie drugiej klasy gimnazjum ze specjalnego ośrodka szkolno-wychowawczego. Piętnaścioro nastolatków - sześciu chłopców oraz dziewięć dziewcząt ze stwierdzoną niepełnosprawnością intelektualną w stopniu lekkim brało udział w eksperymencie (do badania nie zostały udostępnione szczegółowe orzeczenia o dokładnym stopniu niepełnosprawności każdej z osób, co sprawiło, że te dane nie były czynnikiem branym pod uwage w analizie wyników). Najstarsi uczniowie mieli 18 lat (2), sześcioro uczniów było w wieku 17 lat, pięcioro w wieku 16 lat, a najmłodsi uczniowie w tej grupie mieli 15 lat (2), przy czym wiek piętnastu lat jest norma dla tego etapu edukacji zarówno w szkole specjalnej jak i masowej. Rozbieżność wieku wśród uczniów szkoły specjalnej w obrębie jednej klasy nie jest jednak zjawiskiem nadzwyczajnym, gdyż ci uczniowie maja prawo uczęszczać do gimnazjum do ukończenia 21 roku życia. $Z$ powodu różnego typu trudności uczniowie $z$ niepełnosprawnością intelektualną często muszą powtarzać klasy (zazwyczaj ma to miejsce jeszcze w szkole masowej) i stąd taka różnica wieku w jednej grupie. Poziom języka obcego tych uczniów, którzy pobierali edukację z języka angielskiego od czwartej klasy szkoły podstawowej, został określony jako początkujący. W okresie trwania badania, byli oni uczeni przez tego samego nauczyciela i korzystali z książki o tytule „New English Zone 1” (autorzy: Rob Nolasco i David Newbold), przeznaczonej dla uczniów początkujących w masowej szkole podstawowej. Fakt, iż uczestnicy badania byli uprzednio nauczani języka obcego przez okres 4 lat, nie wpłyną znacząco na jego poziom (nadal początkujący). Oprócz podręcznika nauczyciel korzystał z dodatkowych materiałów do książki oraz wprowadzał informacje o kulturze, historii i geografii krajów anglojęzycznych. Zajęcia z języka angielskiego odbywały się w wymiarze 2 godzin tygodniowo. Grupę można opisać jako raczej aktywną chętną do uczestnictwa $\mathrm{w}$ zadaniach i lubiąca wszelkiego rodzaju ćwiczenia angażujące wspólne powtarzanie na głos. Uczniowie chętnie przepisywali słówka, wyrażenia oraz całe zdania $\mathrm{z}$ tablicy do zeszytu, a ponadto byli $\mathrm{z}$ siebie zadowoleni, gdy mogli podchodzić indywidualnie do tablicy, by wykonać przykład z ćwiczenia, np. coś połączyć, narysować czy podpisać. To, zdaniem nauczyciela, stanowiło dla nich szybki dowód na to, że robią postępy i dawało okazję pochwalenia się wiedza na forum klasy. Praca $\mathrm{w}$ parach i sporadycznie w grupach oraz gry językowe, zwłaszcza oparte na słownictwie, należały do najbardziej ulubionych zadań grupy. Uczniowie lubili także ćwiczenia angażujące fizycznie, ale nieśmiałość wielu z nich oraz presja ze strony niektórych rówieśników ograniczała swobodne poruszanie się po klasie i działała demotywująco. Podobne kłopoty były z mówieniem w języku angielskim - grupa odczuwała to jako bardzo trudna czynność i uczniowie niechętnie podejmowali ten trud. Często powodem była niska samoocena. Zeszyty były prowadzone przez 
uczniów $z$ dużą starannością, ale zadania domowe nie były odrabiane przeważnie z powodu trudnych warunków środowiskowych w domu. Z tej przyczyny również głównym miejscem kontaktu z językiem była lekcja w szkole; na samodzielne uczenie się uczniów po szkole nauczyciel nie mógł raczej liczyć. Każde zajęcia zorganizowane były zatem w taki sposób, aby poświęcić ostatnie kilka minut na powtórkę, a krótkie 5-minutowe testy miały miejsce co druga lekcję. Jeśli chodzi o umiejętności językowe uczniów, dosyć dobrze radzili sobie ze słuchaniem, ćwiczeniami pisemnymi oraz czytaniem ze zrozumieniem na głos (czytanie w ciszy powodowało trudności ze skupieniem uwagi i w konsekwencji również złe zachowanie na lekcji). Z powodu słabego myślenia abstrakcyjnego i nieumiejętności stosowania poznanych zasad gramatycznych, budowanie zdań w mowie sprawiało największe kłopoty.

Opisując tę grupę nie należy również zapomnieć o nastawieniu uczniów do samej idei uczenia się języka obcego. Niektórzy z nich byli nastawieni entuzjastycznie, ale inni wręcz przeciwnie, zwłaszcza, gdy nie wierzyli w swoje możliwości porównując się z rodzeństwem ze szkoły masowej, znającym lepiej język angielski. Poza tym, argumenty o lepszej przyszłości dzięki znajomości języka angielskiego nie pomagały im wyobrazić sobie wspaniałej kariery, gdyż dominująca myślą była świadomość bycia w szkole specjalnej... Mimo to jednak, grupa zadawała częste pytania o nazwy wielu rzeczy w języku obcym w odniesieniu do różnych tematów, co świadczyło o ich zainteresowaniu. Ponadto, znaczącym czynnikiem motywującym okazała się świadomość egzaminu gimnazjalnego z języka obcego. Przeprowadzanie próbnych egzaminów było traktowane przez uczniów z powaga.

Z organizacyjnego punktu widzenia, uczniowie tej grupy sprawiali spore problemy $z$ dyscyplina, głównie z powodu nadpobudliwości, a nawet agresji wobec siebie nawzajem. Mieli także spore trudności z wyrażaniem swoich emocji albo nie potrafili nad nimi panować. Nauczyciel często widział konieczność rozmowy z uczniami o ich problemach domowych. Każdy uczeń wymagał osobnego traktowania, pochwał i motywacji.

\section{Procedura badawcza}

Badanie miało miejsce w jednej ze szkół specjalnych w Polsce, do której uczęszczają wyłącznie uczniowie z niepełnosprawnością intelektualną w stopniu lekkim, średnim lub głębokim. Instrumentami badawczymi były: wywiad z nauczycielem prowadzacym oraz 2 testy. Przed eksperymentem uczestnicy badania napisali test sprawdzający znajomość słownictwa. Ułożony w odpowiedni sposób z wykorzystaniem obrazków i typów ćwiczeń z podręcznika, zawierał 4 zadania testujące łącznie 20 haseł leksykalnych, które obejmowały materiał z pierwszego i drugiego rozdziału przerabianego przez nich podręcznika oraz sprawdzał umiejętności receptywne i produktywne. Zadania (w obu testach) wymagały np. połączenia obrazka z odpowiednim wyrazem, podpisania obrazka, zakreślenia odpowiedniego elementu na podstawie słuchania, przyporządkowanie 
polskim wyrazom angielskich odpowiedników (bez obrazka) czy wybór odpowiedniego przymiotnika (z dwóch przeciwnych) opisującego sytuację na obrazku. Tematy leksykalne obu testów obejmowały: przedmioty szkolne (np. a ruler, a chair, a desk), zwierzęta (np. a dog, a cat), liczebniki (do 20), dni tygodnia oraz przymiotniki opisujące codzienne sytuacje (np. noisy/quiet, dirty/clean, new/old). Za każda prawidłową odpowiedź przyznawano 1 punkt. W każdym teście było 20 punktów do zdobycia. Celem testu pierwszego było zgromadzenie danych, do których należało potem odnieść wyniki testu przeprowadzonego po eksperymencie. Po teście wstępnym uczniowie zostali poddani stymulacji mózgu przy użyciu treningu EEG Biofeedback w ilości 10 sesji, jedna tygodniowo. Terapeutami byli pracownicy ośrodka, posiadający specjalistyczne licencje do wykonywania takich zabiegów. Jednocześnie, uczniowie przerabiali na lekcjach trzeci oraz czwarty rozdział z podręcznika kursowego. Po zakończeniu terapii uczniowie napisali drugi test, analogiczny w formie do pierwszego, lecz sprawdzający zapamiętanie słownictwa $\mathrm{z}$ odpowiednio trzeciego i czwartego rozdziału. Metodologia badania o charakterze ilościowym, długotrwałym i preeksperymentalnym (tzn. bez grupy kontrolnej) przedstawiała się następująco:

- zmienna niezależna: stymulacja mózgu osób badanych przeprowadzona metoda EEG Biofeedback; przedstawiona na skali nominalnej

- zmienna zależna: zapamiętanie słownictwa, mierzone dwoma testami (przed i po eksperymencie); przedstawiona na skali interwałowej

- zmienna manipulacyjna: płeć uczniów, przedstawiona na skali nominalnej

- zmienna kontrolowana: wszyscy uczestnicy badania to uczniowie drugiej klasy gimnazjum na podobnym poziomie języka obcego, nauczani przez tego samego nauczyciela, $z$ wykorzystaniem takich samych materiałów i w tym samym czasie oraz poddawani takiej samej ilości sesji stymulujących, bez skali.

Postawiono dwie hipotezy:

Teza 0: Stymulacja mózgn metoda EEG Biofeedback nie ma wptywn na zapamietywanie stownictwa jesyka angielskiego.

Teza 1: Stymulacja mózgu metoda EEG Biofeedback ma posytywny wplyw na zapamietywani stownictwa jesylka angielskiego.

Zgodnie z założeniami teoretycznymi dla metody EEG Biofeedback, stymulacja fal mózgowych $\mathrm{z}$ jej wykorzystaniem nie przynosi skutków ubocznych, dlatego też nie przewidywano, aby sesje mogły w jakikolwiek sposób zaszkodzić badanym czy mieć negatywny wpływ na zapamiętywanie słownictwa, pod warunkiem jednak, że treningi sa przeprowadzane prawidłowo przez osoby do tego uprawnione. Pozytywny wpływ metody miał przejawiać się poprzez lepsze zapamiętanie słownictwa poznanego na lekcjach, odzwierciedlone większą ilością zdobytych punktów w teście przeprowadzonym po eksperymencie. 
Badanie przebiegło w zamierzony sposób. Stymulację przeprowadzono, a wyniki obu testów zostały porównane przy zastosowaniu następujących obliczeń: średnia obu testów, odchylenie standardowe wskazujące na różnice między wynikami oraz test Studenta T informujący o tym, czy różnice w wynikach testu są istotne statystycznie. Po sprecyzowaniu danych wyciagnięto następujące wnioski:

po obliczeniu osobnej średniej dla każdego z testów oraz odchylenia standardowego uzyskane wartości wskazały, że test końcowy wypadł lepiej niż wstępny, co obrazuje Tabela 1 poniżej:

\begin{tabular}{|l|l|l|}
\hline & Test 1 - wstępny & Test 2 - końcowy \\
\hline Średnia & 14,27 & 16,47 \\
\hline Odchylenie standardowe & 3,35 & 1,48 \\
\hline
\end{tabular}

Tabela 1: Wartości średniej i standardowego odchylenia dla testu wstępnego i końcowego.

Z wartości średnich obliczonych dla obu testów wynika, że uczestnicy badania udzielili więcej poprawnych odpowiedzi pisząc test końcowy. Jeśli zaś chodzi o odchylenie standardowe, jest ono homogeniczne dla testu końcowego, co oznacza, że nie było znacznych różnic między wartościami punktów zdobytych przez poszczególnych badanych. Z uwagi na fakt, że dwoje uczniów uzyskało wynik maksymalny, czyli 20 punktów, a troje 19 punktów, można zakładać, że pozostałe $2 / 3$ grupy badawczej również zdobyło wysoką ilość punktów, gdyż odchylenie standardowe jest relatywnie niskie. Stosunek testu końcowego do wstępnego przedstawia poniższy Wykres 1:

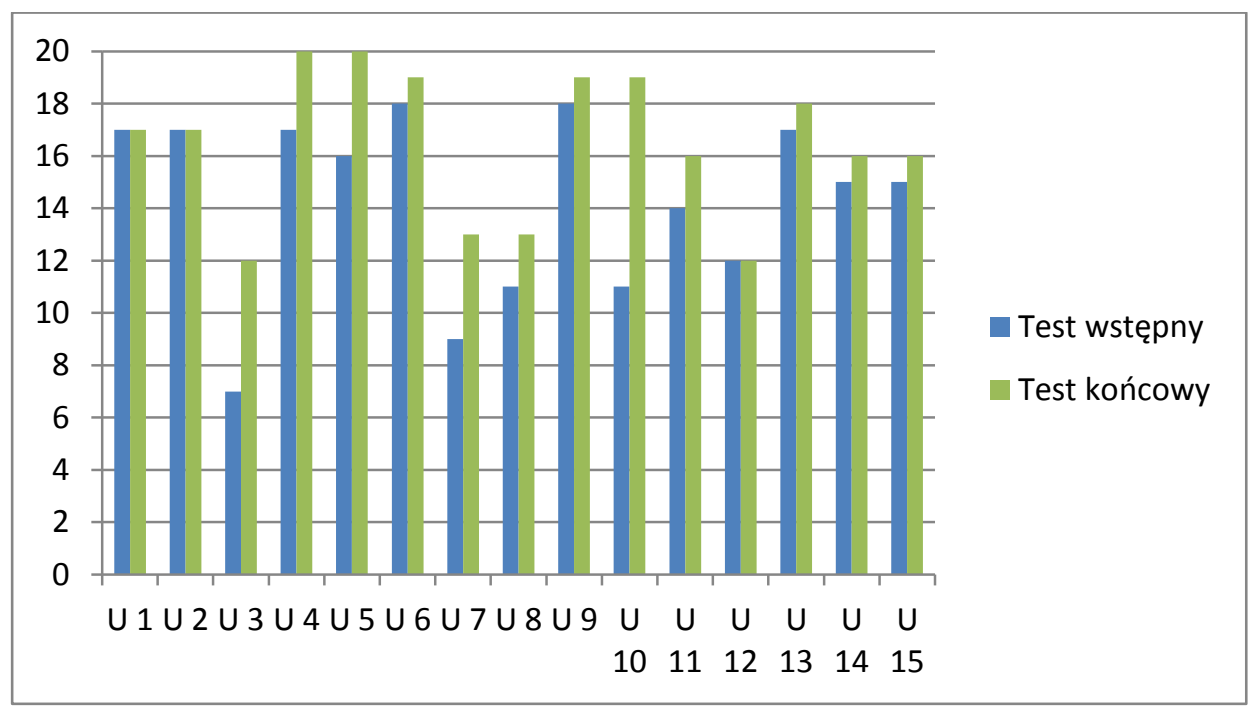

Wykres 1: Wyniki testu wstępnego oraz końcowego. 
Z powyższego wykresu wynika, że najniższy wynik w teście wstępnym to 7 punktów, a w końcowym 12, przy czym 2 osoby osiagnęły maksimum, co nie miało miejsca w teście wstępnym. Ponadto, próg zdobytej punktacji na poziomie $80 \%$ lub więcej (w tym przypadku 16 punktów na 20 ) został osiagnięty przez 73,3\% badanych w teście końcowym w porównaniu z 46\% w teście wstępnym. Bez wątpienia wskazuje to na znaczną poprawę ogólnego wyniku testu końcowego - o około $30 \%$.

Oprócz powyższych wskaźników obliczono także test Studenta T dla prób zależnych, który wykazał, że tezę 0 należy odrzucić, gdyż T zaobserwowane $(1,81)$ okazało się wyższe niż $\mathrm{T}$ krytyczne $(1,761)$ ustanowione dla tego badania na poziomie istotności $\alpha=0,05$. Oznacza to tym samym, że teza 1 została $\mathrm{w}$ badaniu potwierdzona - stymulacja mózgu w treningach metodą EEG Biofeedback ma pozytywny wpływ na zapamiętywanie słownictwa języka angielskiego u uczniów z niepełnosprawnością intelektualną w stopniu lekkim. Różnica w wynikach między testem wstępnym i końcowym jest znacząca statystycznie. Niemniej jednak należy pamiętać, iż z przyczyn niezależnych od osoby badającej, w badaniu wzięło udział 15 osób i wynik należy uznać za dowód istnienia jedynie pewnej tendencji. Obecnie przez okres 2 lat prowadzone jest podobne badanie, lecz z udziałem większej liczby osób, sesji treningowych i z uwzględnieniem przyswajania języka obcego w szerszej perspektywie, niż zakres leksykalny.

\section{Rozważania o przyszłości}

Pomysł nauczania języka obcego uczniów z niepełnosprawnością intelektualną w stopniu lekkim od początku był i nadal jest kontrowersyjny. Nauczanie takich osób jest trudne podobnie jak odnoszenie przez nich sukcesów. Niemniej jednak, język obcy w ich szkole jest obecny $i$ jak na razie nic nie wskazuje na to, by miało się to zmienić. Dowodem jest zmiana z roku 2009 i podniesienie poprzeczki za pomocą egzaminu gimnazjalnego $z$ języka obcego. Nie oznacza to jednak katastrofy, gdyż egzamin jest dostosowany do specjalnego programu, a proces nauczania można stale udoskonalać oczekując jednocześnie coraz lepszych efektów uczenia się. W dotarciu z przekazem do ucznia o specjalnych potrzebach intelektualnych i emocjonalnych może pomóc właśnie trening EEG Biofeedback, poprzez korzystny wpływ na wzmocnienie koncentracji uczniów, którzy często maja problemy ze skupieniem uwagi. Wynik przeprowadzonego przeze mnie badania, podobnie jak wspomniane na początku doświadczenia innych nauczycieli pokazuja, że można nauczyć uczniów niepełnosprawnych intelektualnie języka obcego choćby w takiej jego części, jak wyrażenia leksykalne i z sukcesem na miarę możliwości, jakie ci uczniowie posiadaja. Tak jak w każdej grupie, sa tu jednostki słabsze i silniejsze, co oznacza, że nawet jeśli kilka osób w grupie nauczy się rozumieć i składać choćby kilka prostych zdań w języku angielskim, to i tak jest to o wiele więcej, niż gdyby nikt $z$ nich tego języka nie był uczony. A urządzenie EEG Biofeedback daje nadzieję, że warto starać się o nie dla szkoły, zwłaszcza, że 
jeśli następuje poprawa kontroli nad własną koncentracją w przypadku ucznia trudnego, poprawią się jego możliwości sensomotoryczne nie tylko na lekcjach języka obcego, ale także na wszystkich innych przedmiotach.

W XXI wieku, który oferuje bardzo zaawansowane rozwiązania technologiczne, należy zaufać stale pojawiającym się nowym możliwościom i z odwaga wprowadzać je w życie, czyniąc je łatwiejszym. Zwłaszcza takiej formy pomocy potrzebują osoby $z$ niepełnosprawnością intelektualną, gdyż zaburzenie rozwojowe tego typu leży u podstaw niemal wszystkich pozostałych aspektów życia, wywierając na nie duży wpływ. Im bardziej uda nam się przystosować jednostki słabsze do normalnego funkcjonowania w społeczeństwie, tym będzie ono lepsze. A dążenie do udoskonalenia jest zobowiązaniem, które mamy wobec coraz szybciej rozwijającej się cywilizacji naszych czasów.

\section{BIBLIOGRAFIA}

Barnow, S., Ermer, A., Dittmann, V., Stieglitz, R. 2005. „Upośledzenie umysłowe". Kompendium Psychiatrii, Psychoterapii, Medycyny Psychosomatycznej. Warszawa: Wydawnictwo Lekarskie PZWL. 208-214.

EEG Instytut 2006. Audiowizualna stymulacja mózgu. Materiaty szkoleniowe. Warszawa: EEG Instytut.

EEG Instytut Biofeedback 2010. http:/ /www.eeg.com.pl (DW: 01.10.2010).

Lamparska-Warchalska, A. 2010. „EEG Biofeedback - nowe możliwości terapeutyczne". Psychologia.net.pl - Portal psychologiczny. http:/ / www.psychologia. net.pl/artykul.php?level=170 (DW: 01.10.2010).

Mąkosa, J. 2001. „Kształcenie języków obcych u uczniów z upośledzeniem umysłowym w stopniu lekkim (na przykładzie języka angielskiego)". Poradnik metodyczny dla nauczycieli ksztatcacych uczniów z. upośledzeniem umystowym w stopniu lekekim w szkołach ogólnodostępnych i integracyjnych. Warszawa: MEN. $160-168$.

Pakszys, M. 2006. Neurotechnologia i neurofizjologia. Materiaty szkoleniowe. Warszawa: EEG Instytut.

Patton, J., Polloway, E. i Smith, T. 2000. „Educating students with mild mental retardation." Focus on autism and other developmental disabilities vol. 15, 2. Hammill Institute on Disabilities http://foa.sagepub.com/content/15/2.toc 80-89. (DW: 01.10.2010).

Seifert, K. 1983. Educational psychology. Boston: Houghton Mifflin Company.

Siwek, S. 2006. „Upośledzenie umysłowe”. Neuropsychologia kliniczna dziecka. Warszawa: PWN. 31-88.

Wieruszewska, M. 2007. „Egzamin gimnazjalny z jezzyka angielskiego”. The teacher 10 (52). Warszawa: Oxford University Press. 8-13.

Włodarski, Z. 1976. Psychologiczne prawidłowości uczenia się i nauczania. Warszawa: WSiP. Zegarek, L. i Roczniak, I. 2001. „Sylwetka Mateusza - charakterystyka ucznia z upośledzeniem w stopniu lekkim". Poradnik metodyczny dla nauczycieli 
Rola biostymulacji mózgu w uczeniu się języka angielskiego przez nastolatków ...

ksztatcacych uczniów z. upośledzeniem umystowym w stopniu lekkim w sžkołach ogólnodostępnych i integracyjnych. Warszawa: MEN. 30-34. 